\title{
Reproductive cycle of Macrobrachium amazonicum females (Crustacea, Palaemonidae)
}

\author{
Sampaio, CMS. *, Silva, RR., Santos, JA. and Sales SP. \\ Laboratório de Carcinicultura, Centro de Ciências da Saúde, Universidade Estadual do Ceará, \\ Av. Paranjana, 1700, CEP 60740-903, Fortaleza, CE, Brazil \\ *e-mail: cmsamp@uece.br \\ Received October 13, 2005 - Accepted March 24, 2006 - Distributed August 31, 2007
}

(With 5 figures)

\begin{abstract}
Macrobrachium amazonicum is considered a favorite Brazilian species of freshwater prawn for cultivation as a result of its quick development and because it is easy to maintain in captivity. The aim of this work is to describe the sexual cycle stages and determine maturation age of the female M. amazonicum, which was collected monthly from June, 2002 to May, 2003 in the Jaguaribe River, Itaiçaba, Ceará. A monthly sample of water was also collected to determine the following parameters: temperature, dissolved oxygen, $\mathrm{pH}$ and salinity. A monthly sample of females was selected among the individuals caught, to determine the total weight $\left(\mathrm{W}_{\mathrm{T}}\right)$, carapace length $\left(\mathrm{L}_{\mathrm{C}}\right)$ and abdomen+telson length $\left(\mathrm{L}_{\mathrm{A}+\mathrm{T}}\right)$ and to register the number of non-ovigerous females (NOF) and ovigerous females (OF). Determining ovarian maturation stages of $M$. amazonicum was done in a laboratory by observing macroscopic characters such as coloring, size, location and appearance of ovarians examined by transparent carapace. The first maturation age was determined from the relative frequency of the total length $\left(\mathrm{L}_{\mathrm{T}}\right)$ of young and adult females. The environmental parameters of the Jaguaribe River did not hold any influence in the number of individuals collected. A total of 1,337 prawns were sampled, 513 males $(38.4 \%)$ and 824 females $(61.6 \%)$. The proportion between males and females in the studied population was of $1: 1.6$. Among the collected females, $492(50.7 \%)$ did not carry eggs in their abdomens (NOF) and $332(40.3 \%)$ carried eggs in their abdomens (OF). There was no record of intact females. Non-ovigerous females with mature ovaries were recorded throughout all the months of collection. The female ovaries were classified as immature (IM), rudimentary (RU), intermediary (IN) and mature (M). M. amazonicum females reach their first sexual maturity between 4.5 and $5.5 \mathrm{~cm}$ of total length.
\end{abstract}

Keywords: reproduction, reproductive cycle, Macrobrachium amazonicum.

\section{Ciclo reprodutivo de fêmeas de Macrobrachium amazonicum (Crustacea, Palaemonidae)}

\section{Resumo}

Das espécies de camarão de água doce brasileiras, Macrobrachium amazonicum é a preferida para cultivo, devido ao seu rápido desenvolvimento e fácil manutenção em cativeiro. Este trabalho teve como objetivos caracterizar as fases do ciclo sexual e determinar a idade da primeira maturação de fêmeas de $M$. amazonicum, coletadas mensalmente, de junho de 2002 a maio de 2003, no Rio Jaguaribe, Itaiçaba, Ceará. Uma amostra de água do local foi coletada mensalmente para determinação dos seguintes parâmetros: temperatura, oxigênio dissolvido, pH e salinidade. Do total de indivíduos capturados mensalmente, uma amostra de fêmeas foi selecionada para determinação do peso total $\left(\mathrm{W}_{\mathrm{T}}\right)$, do comprimento do cefalotórax $\left(\mathrm{L}_{\mathrm{C}}\right)$ e do abdômen+telson $\left(\mathrm{L}_{\mathrm{A}+\mathrm{T}}\right)$, e para registro de fêmeas não ovígeras (FNO) e ovígeras (FO). A determinação macroscópica dos estágios de maturação ovariana de M. amazonicum foi realizada pela observação da coloração, do tamanho, da posição e da aparência dos ovários observados por transparência da carapaça. A idade da primeira maturação foi determinada a partir da freqüência relativa de comprimento total $\left(\mathrm{L}_{\mathrm{T}}\right)$ de fêmeas jovens e adultas. Os parâmetros ambientais do Rio Jaguaribe não influenciaram no número de indivíduos coletados. Foram amostrados um total de 1.337 camarões, sendo 513 machos $(38,4 \%)$ e 824 fêmeas $(61,6 \%)$. A proporção entre machos e fêmeas na população foi de 1:1,6. Entre as fêmeas coletadas, $492(50,7 \%)$ não carregavam ovos no abdômen e $332(40,3 \%)$ carregavam ovos no abdômen. Não foram observadas fêmeas intactas. Foram registradas fêmeas não ovígeras com ovários maduros durante todo o período de coleta. Os ovários das fêmeas foram classificados como: imaturo (IM), rudimentar (RU), intermediário (IN) e maduro (M). Fêmeas de M. amazonicum atingem a primeira maturação sexual com comprimento total variando entre 4,5 e $5,5 \mathrm{~cm}$.

Palavras-chave: reprodução, ciclo reprodutivo, Macrobrachium amazonicum. 


\section{Introduction}

According to data from the FAO, mentioned by Valenti (2002), worldwide prawn production went from 21,000 to 118,500 t yearly between 1990 and 2000, which corresponds approximately to a $500 \%$ growth, and to this we should add roughly $27,000 \mathrm{t}$ of "other prawns and crustaceans" registered by Vietnam, bearing in mind this production refers to $M$. rosenbergii; as well as $M$. nipponense, which in China was of the order of $100,000 \mathrm{t}$ in 2000 . Therefore, the worldwide production of prawns surpassed 240,000 $t$ in 2000, an amount considered historical since this represents approximately $20 \%$ of the total amount manufactured, when taking into account that for a long time it was only $5 \%$.

The term prawn has a very broad meaning. It is used to characterize species whose entire life cycle is restricted to freshwater, as well as to those that need brackish water at the beginning of their development and later freshwater, after metamorphosis (New, 2002).

Prawns are decapod crustaceans belonging to the Suborder Pleocyemata, Infraorder Caridea, Superfamily Palaemonoidea and Family Palaemonidae (Martin and Davis, 2001). Although they are also called prawns, like salt water shrimps, they are considered closer to lobsters, since they share many similarities, mainly regarding their reproductive habits because the prawn females, similar to lobsters, keep their eggs in the abdomen until spawning time (Valenti, 1990).

Most of the prawn species of commercial interest belong to the Macrobrachium Bate, 1868 genus, distributed in the tropical and subtropical regions of the world (Jalihal et al., 1993). According to (Holthuis, 2000) this genus is cincumtropical and indigenous to all continents, except Europe. Currently, there are nearly 210 species of the Macrobrachium genus known in the world (Short, 2004), of which 45 are registered in the Americas and 18 in Brazil (Melo, 2003).

In the early 1970s, researchers from the Oceanography Department of the Federal University of Pernambuco (DOUFPe) began to study three of the most important Brazilian native species: $M$. acanthurus, $M$. amazonicum and $M$. carcinus. Their objective was to develop adequate technology for their cultivation (Coelho and Ramos-Porto, 1985). However, due to importation of post-larvae of $M$. rosenbergii from Hawaii by DOUFPe in 1977, and the development of its cultivation worldwide, studies related to our species underwent discontinuity (Valenti, 1992; 1993). Notwithstanding and despite advances achieved in the cultivation of $M$. rosenbergii all over the world, it is necessary to study the life cycle, reproduction, growth and habitat of these species once again.

Among the native Brazilian species, M. amazonicum is the selected choice for cultivation, owing to its rapid growth and easy maintenance in captivity. Despite its growth being smaller than other species of the same genus, they do not seem to have the aggressive characteristic of $M$. acanthurus and $M$. carcinus, apart from the fact that they are more resistant to illness and predators (Lobão and Rojas, 1991).

M. amazonicum is an indigenous species and vastly distributed in many basins of South America, of the Amazon River, of Northeastern Brazil, of the São Francisco River and of the Paraguay River (Bialetzki et. al., 1997). This species was brought over from the Amazon Bay to the Brazilian Northeastern region in the 1940s and was introduced by the Fishery Services of the National Department of Services Against Droughts (DNOCS) in several dams of the region as forager species for carnivorous fish. Owing to its immediate acclimatization and quick reproduction, it spread to several dams and rivers of the area, thus becoming among the most important fishing resources (Gurgel and Matos, 1984; Paiva and Campos, 1995).

The works of Odinetz Collart (1991a, b); Chaves and Magalhães (1993); Odinetz Collart (1993), Odinetz Collart and Magalhães (1994) and Silva et al. (2002) emphasized various reproduction aspects of $M$. amazonicum collected in rivers in the Northern region. Pinto (1977); Freitas et al. (1979); Gurgel and Matos (1984); Scaico (1992) and Bragagnoli and Grotta (1995), studied the reproduction of M. amazonicum in the Northeast area, but with prawns captured in public dams, conducted by DNOCS not in rivers. Lobão et al. (1986) and Porto (1998) used samples of species collected in rivers of the Southeast and Mid West region, respectively.

There is little information concerning the population structure and reproduction biology of M. amazonicum collected in state rivers of Ceará. In their papers, Rebouças (2002), Santos (2003) and Silva et al. (2002) determined the morphometric relationships of male and female, female fertilization and fertility, and the morphotypic distinctiveness of the $M$. amazonicum male collected in the River Jaguaribe, Itaiçaba, Ceará, respectively.

Therefore, it has become necessary to continue studies of this species in order to develop cultivation technology appropriate for the reality of the Brazilian Northeast and thus enable farmers to have alternative species for cultivation.

The objective of this work is to establish and categorize phases of the sexual cycle of $M$. amazonicum females collected in the Jaguaribe River, Itaiçaba, Ceará Brazil, its annual distribution and its relationship with the abiotic factors and also to determine the first maturation size of $M$. amazonicum female.

\section{Materials and Methods}

\subsection{Location of collection}

The collection was carried out in the River Jaguaribe, Itaiçaba, Ceará, located above Work Channel dam, at $200 \mathrm{~m}$ latitude and $04^{\circ} 40^{\prime} 28^{\prime \prime} \mathrm{S}$ and $37^{\circ} 49^{\prime} 21^{\prime \prime} \mathrm{W}$.

The Jaguaribe River is $633 \mathrm{~km}$ long and is divided into three basins: Jaguaribe High, Medium and Low. In 
the lower part, where the dam is located, the river runs along $137 \mathrm{~km}$ and flows into the Atlantic Ocean in the city of Aracati (Iplance, 1995).

\subsection{Environmental parameters}

The temperature, $\mathrm{pH}$, salinity and dissolved oxygen were determined monthly. The water was collected at $6 \mathrm{~m}$ deep with a Van Dorn bottle.

The temperature was determined with a regular thermometer (Incoterm), $\mathrm{pH}$ with a pocket $\mathrm{pH}$-meter (Orion, Quikchek) and salinity with a portable refractometer (Alfakit, 211 model). The oxygen dissolved was determined in laboratory using the Winkler method.

The monthly data of pluviometer precipitation were supplied by the Foundation for Meteorology and Water Resources from the State of Ceará (FUNCEME).

\subsection{Collected material}

Specimens of M. amazonicum were collected monthly during the months of June, 2002 and May, 2003. The prawns were captured with casting nets of $5.0 \mathrm{~m}$ diameter and mesh with openings of $20.0 \mathrm{~mm}$ between knots. The trap was thrown from a raft into a sandy bottom, always at the beginning of the morning for one hour. After collecting, the prawns were transported alive to the Biological Science Laboratory in the State University of Ceará (LABIO/UECE).

The prawns were separated and identified using classification keys proposed by Holthuis (1952), GomesCorrea (1977); Holthuis (1980); Rodriguez (1980), Williams (1984) and Melo (2003). Sex differentiation took place by means of observation of the endopodite morphology of the second pair of pleopods, as proposed by Ismael and New (2000).

A monthly sample of up to 150 individuals of $M$. amazonicum of both sexes was selected randomly, regardless of the number of prawns collected. In this paper, only females were used, the males were separated for posterior studies.

The females were divided into three groups, according to their reproductive stage. The first group was composed of non-ovigerous females (NOF), the ones that had an abdominal incubator cavity, showing traces of previous spawns; the second group was of ovigerous females (OF), those with pleopods carrying eggs and the third group was of intact females (IF), those that did not have an abdominal cavity.

\subsection{Morphometric data}

For each of the three female groups, the total weight $\left(\mathrm{W}_{\mathrm{T}}\right)$; carapace length $\left(\mathrm{L}_{\mathrm{C}}\right)$ and abdomen+telson length $\left(\mathrm{L}_{\mathrm{A}+\mathrm{T}}\right)$ was determined. The total length $\left(\mathrm{L}_{\mathrm{T}}\right)$ is the sum of the last ones added.

The length measures were obtained using a steel caliper ruler with precision of $0.05 \mathrm{~mm}$ (Mitutoyo, caliber $150 \mathrm{~mm} \times 6$ "). The total weight was determined by a semi-analytic scale with a precision of $0.1 \mathrm{~g}$ (Gehaka Model BG 2000).

\subsection{Ovarian maturation stages}

Determining the ovarian maturation stages of $M$. amazonicum was done by observing macroscopic characters such as coloring, size, location and appearance of the ovary observed by transparent carapace according to criteria established by Porto (1998) for M. amazonicum and adapted by Carvalho and Pereira (1981) and Carvalho-Pinheiro (1983) for M. acanthurus.

\subsection{Size of first maturation}

According to Vazzoler (1982), the first sexual maturation is reached at the time when $50 \%$ of the individuals of a population go into gonadic activity at maturation stage. To determine the first maturation size, the total length monthly data of females were used, considering two groups: 1) young females: those with immature gonads and 2) adult females: those with gonads in maturation, mature and empty, meaning, all that are not immature. Afterwards, the relative frequency of immature and mature females was obtained for each length class.

Data relating to the total length of each of the two categories referred to above were plotted in the graph and $\mathrm{X}$ was the total length and $\mathrm{Y}$ the relative frequency of females. The intersection point of the two curves indicated in which total length class the average size of the females in their first maturation is located.

\section{Results}

\subsection{Environmental parameters}

During monthly collection, the water temperature varied between $29.0 \pm 1.13{ }^{\circ} \mathrm{C}$; dissolved oxygen between $5.9 \pm 0.66 \mathrm{mg} . \mathrm{L}^{-1}$ and $\mathrm{pH}$ between $7.9 \pm 0.37$. Monthly salinity throughout the entire period was equal to $0 \mathrm{ppt}$. It was impossible to collect water in July; therefore the environmental parameters were not determined in this month (Table 1).

Table 1. Monthly distribution of environmental parameters of the Jaguaribe River, Ceará, from June, 2002 to May, 2003.

\begin{tabular}{cccc}
\hline Month & $\begin{array}{c}\text { Temperature } \\
\left({ }^{\circ} \mathbf{C}\right)\end{array}$ & $\begin{array}{c}\text { Dissolved } \\
\text { Oxygen }\left(\mathbf{m g} .{ }^{\mathbf{L}-1}\right)\end{array}$ & $\mathbf{p H}$ \\
\hline $06 / 2002$ & 27.5 & 6.0 & 8.0 \\
$08 / 2002$ & 27.5 & 5.5 & 8.3 \\
$09 / 2002$ & 28.5 & 7.2 & 8.4 \\
$10 / 2002$ & 27.0 & 6.1 & 8.4 \\
$11 / 2002$ & 27.5 & 6.1 & 7.6 \\
$12 / 2002$ & 28.0 & 5.7 & 8.0 \\
$01 / 2003$ & 29.0 & 5.1 & 7.4 \\
$02 / 2003$ & 29.0 & 4.6 & 7.4 \\
$03 / 2003$ & 29.0 & 5.4 & 7.8 \\
$04 / 2003$ & 29.0 & 5.7 & 7.6 \\
$05 / 2003$ & 31.0 & 5.5 & 7.8 \\
X \pm s.d & $29.0 \pm 1.13$ & $5.9 \pm 0.66$ & $7.9 \pm 0.37$ \\
\hline
\end{tabular}




\subsection{Population structure}

A total of 1,337 prawns were collected, 513 males $(38.4 \%)$ and 824 females $(61.6 \%)$. The population proportion between males and females was of 1:1.6.

Absolute frequency of $M$. amazonicum females was higher than males in nine of the twelve months of collection, with marked decrease of their number in the period between November, 2002 and January, 2003 (Figure 1).

\subsection{Reproductive cycle}

Among the collected females, $332(40.3 \%)$ carried eggs in their abdomen and $492(50.7 \%)$ did not. No intact females were recorded.

Ovigerous $M$. amazonicum females were found during the entire year. However, recurrence of non-ovigerous females was higher than ovigerous in ten of the twelve months of collection, at which time they markedly reduced in number in the period between November/2002 and January/2003 (Figure 2).

\subsection{Ovarian maturation stages}

It was possible to detect four ovarian development stages: Immature (IM), Rudimentary (RU), Intermediary (IN) and Mature (M) for M. amazonicum females captured in the Jaguaribe River, Itaiçaba, Ceará.

Females belonging to this species were found in all stages of ovarian development, ovigerous as well as non-ovigerous. The relative frequency of non-ovigerous females in mature stages has always been higher than ovigerous females in the same stage. On the other hand, the relative frequency of ovigerous females in an immature stage was higher than non- ovigerous females in the same stage, although mature females were found throughout the entire year, even at low frequencies (Figures 3 and 4, respectively).

\subsection{Size of first maturation}

To determine the size of first maturation, the total lengths of $768 \mathrm{M}$. amazonicum females were used, 271 were young and 479 were adult.

Considering that $50 \%$ of the non-ovigerous and ovigerous $M$. amazonicum females showed mature gonads in the total length classes situated between 4.5-5.0 and 5.0 and $5.5 \mathrm{~cm}$, it could be suggested that the first gonad maturation of this species occurs between these classes (Figure 5).

\section{Discussion}

\subsection{Environmental parameters}

According to Zimmermann (1998), the shrimps show physiological response to physical and chemical factors that are most important in their habitat. In a cultivation

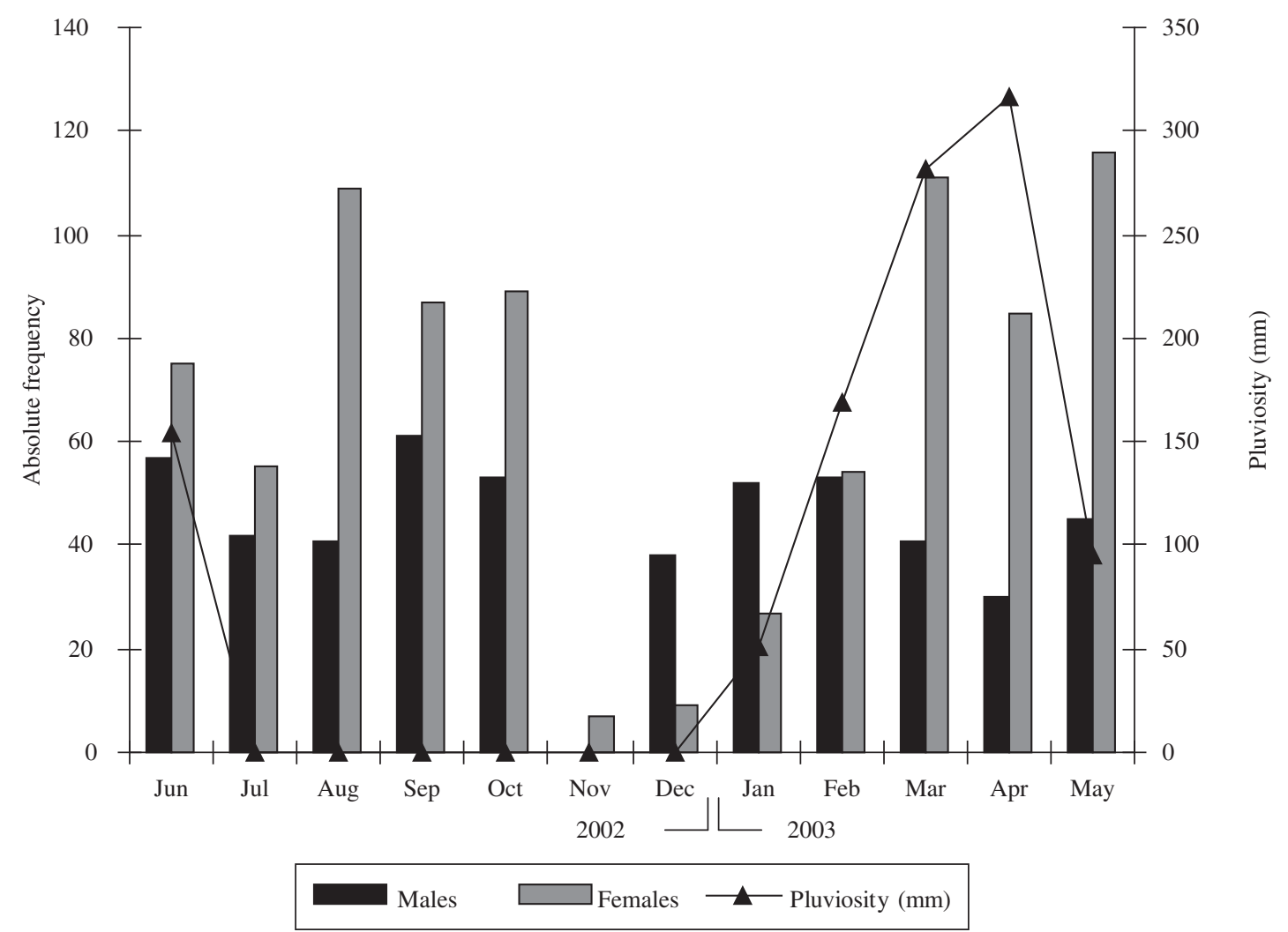

Figure 1. Monthly absolute frequency distribution of M. amazonicum collected from June, 2002 to May, 2003 in the Jaguaribe River, Ceará. 


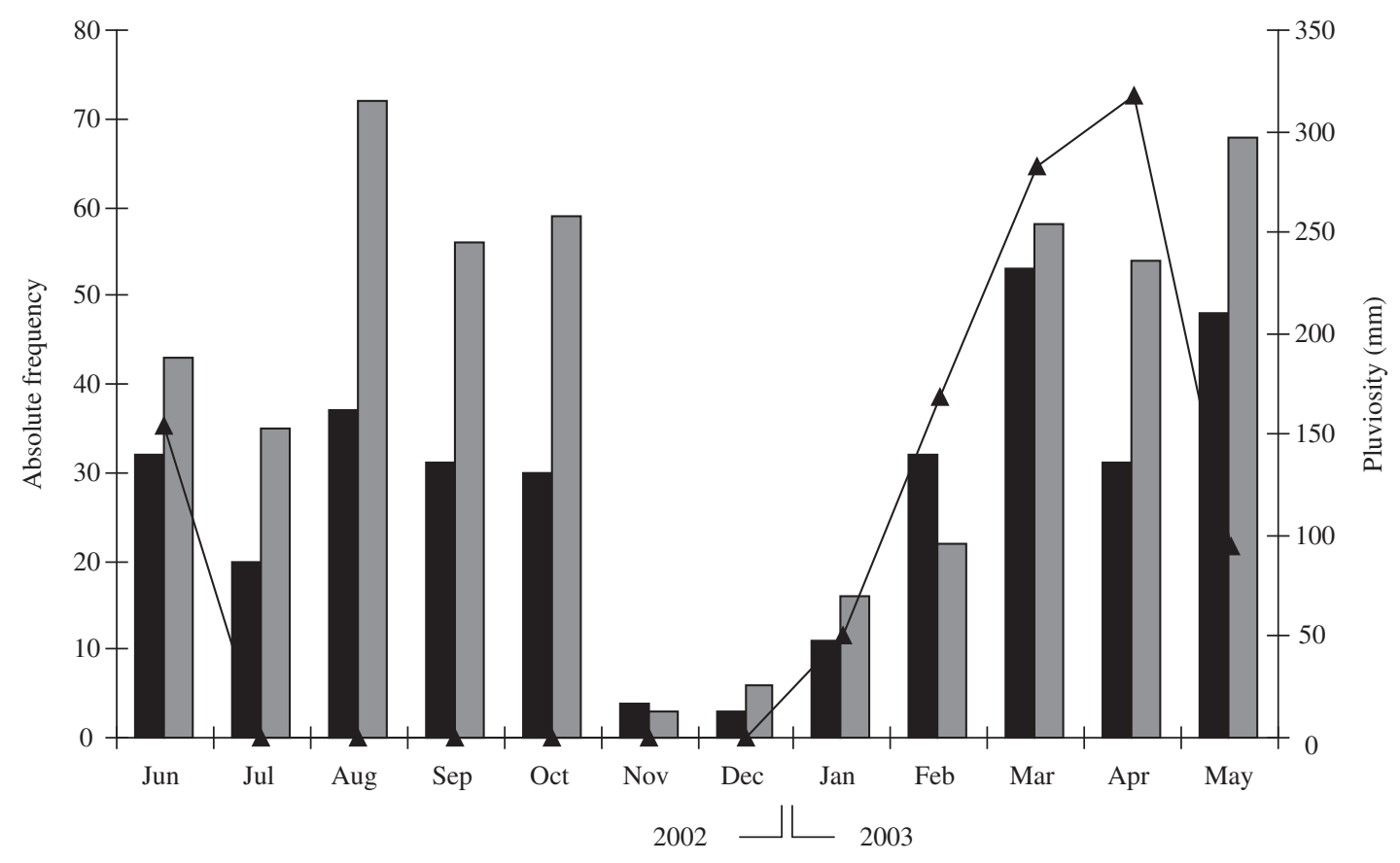

Ovigerous females $\square$ Non ovigerous females $\quad \longleftarrow$ Pluviosity (mm)

Figure 2. Monthly absolute frequency distribution of ovigerous and non-ovigerous females of M. amazonicum collected from June, 2002 to May, 2003 in the Jaguaribe River, Ceará.

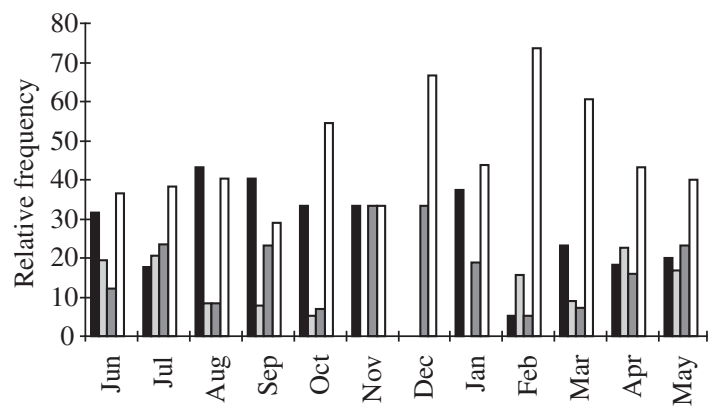

- Immature $\square$ Rudimentary $\square$ Intermediary $\square$ Mature

Figure 3. Monthly relative frequency distribution of maturation ovarian stages for non-ovigerous females of M. amazonicum

nursery, the water temperature and the dissolved oxygen dominate the behavior and the physiology of most of the aquatic organisms. While the temperature controls the molecular dynamic and most of the chemical reactions, the dissolved oxygen acts as the main limitation factor in the biochemical reactions controlled by the temperature. According to Sipaúba-Tavares (1998), the temperature, dissolved oxygen, $\mathrm{pH}$ and water salinity often interfere

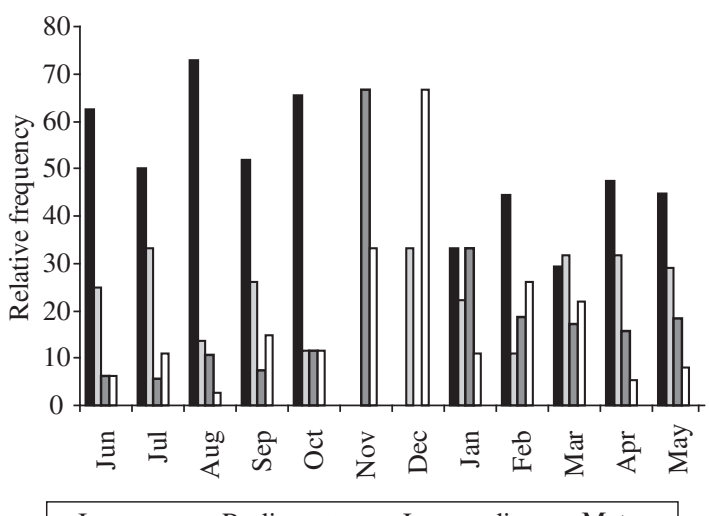

Figure 4. Monthly relative frequency distribution of maturation ovarian stages for ovigerous females of M. amazonicum.

in the reproduction, distribution and periodicity of organisms.

Valenti (1996) and Pinheiro and Hebling (1998) reported that in natural environments, the reproduction of $M$. rosenbergii is usually continuous throughout the whole year. However, this presents higher density in the months when the environmental factors are more favorable to the gonadal development and to offspring survival. 


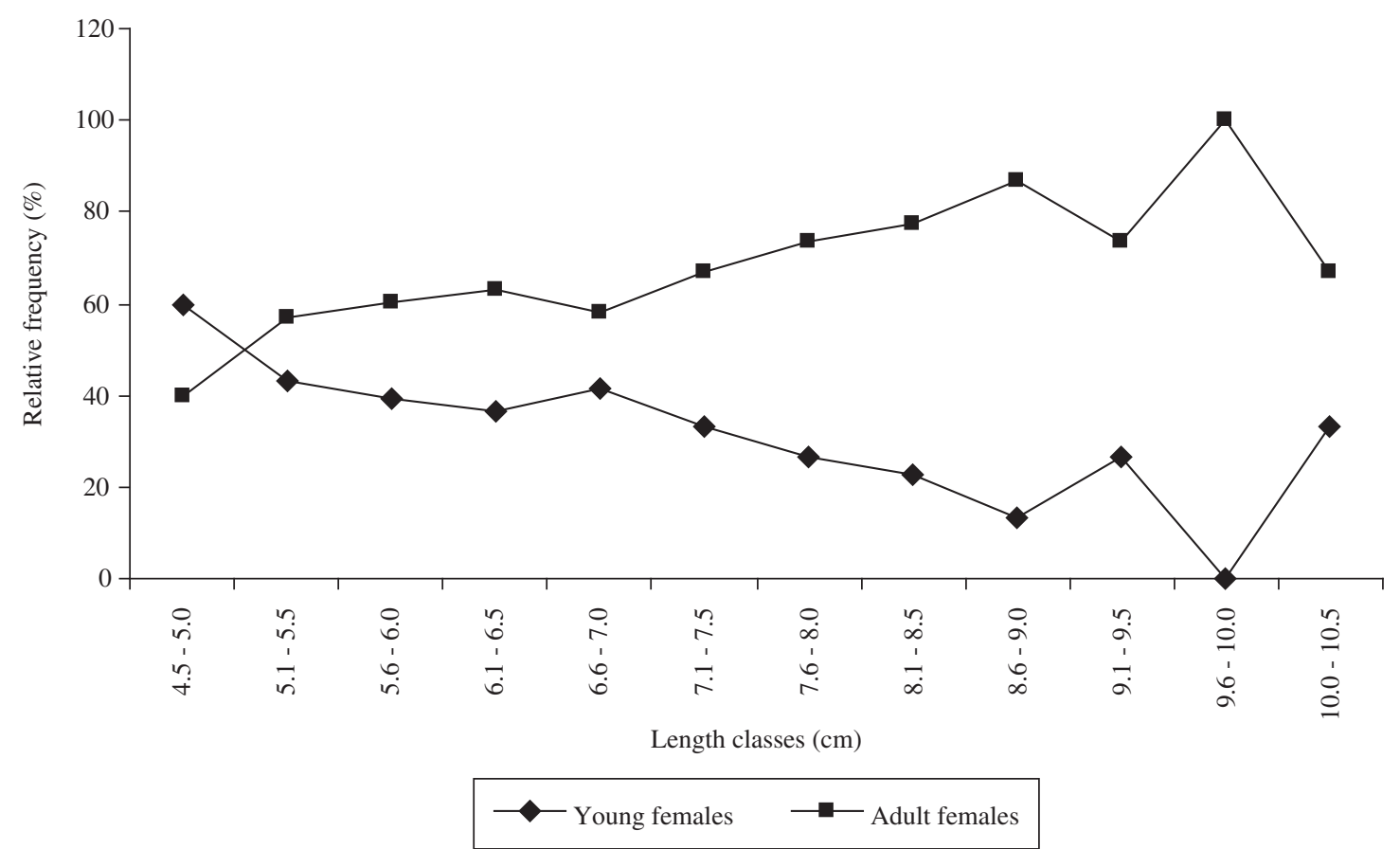

Figure 5. Size of first maturation for M. amazonicum females.

Ammar et al. (2001), when analyzing the reproductive biology of the $M$. olfersi collected on the Island of Santa Catarina, Brazil; point out that temperature and salinity oscillation may have influenced the size of the population and variations of the individuals. This fact is compatible with what Mossolin and Bueno (2002) report in a study also carried out with $M$. olfersi from São Sebastião, São Paulo, Brazil, in which the periods of more reproductive activity coincide with the months when the temperature was higher, on the other hand, with opposite occurrences in the colder months.

According to Bond and Buckup (1982), M. potiuna and $M$. borelli reproductive cycles are more strongly stimulated by seasonal light variation than by thermal water fluctuations. These authors also inferred that in equatorial regions and even in low latitudes, a light influence is less significant due to the small variation of the length of the day.

The physical-chemical parameters that were analyzed did not have an influence in the quantity of collected organisms in the natural population of M. amazonicum in the Jagaribe River, Itaiçaba, Ceará, because, although the number of males, non-ovigerous and ovigerous females have varied quite considerably throughout the collection period, the physical-chemical parameters present little variation since they were in the zone suggested by New (2002) for the tropical species of this genus.

Owing to the fact that the location is in an equatorial region, the water temperature was always high, perhaps favoring the occurrence of ovigerous females in all months. It is worth mentioning that the values observed are found within the ideal zone referred by Sampaio and
Valenti (1996) for $M$. rosenbergii, which are cultivated in ponds.

Ours data is compatible with work by Biswas and Qureshi (1994), who observed that the natural population of $M$. dayanum shows seasonal variations of density. However, these authors did not find any straight connection of the population density variation to the temperature, $\mathrm{pH}$, dissolved oxygen or free $\mathrm{CO}_{2}$.

Another exogenous factor that can have an effect in the reproductive cycle of $M$. amazonicum is the pluviometric configuration. Bragagnoli and Grotta (1995) observed that the highest percentage of ovigerous $M$. amazonicum females occurred in the months with the highest pluviometric precipitation, while Gamba (1984) studying $M$. amazonicum and $M$. jelskii reproduction also observed that the highest number of ovigerous females of this species was collected at the beginning of the rain season. On the other hand, Lobão et al. (1978) demonstrated an inversed relation between mature $M$. holthuisi females in pluviometric precipitation.

The non existence of any relationship between pluviometric precipitation in the region of the Jaguaribe River and the occurrence of ovigerous females is reinforced by the observations made by Sagi and Ra'anan (1988), who in their studies affirm there is no relationship between the reproductive stages of $M$. rosenbergii and the seasonal changes.

\subsection{Population structure}

The proportion between males and females in the natural population of $M$. amazonicum collected in the Jaguaribe River, Ceará was quite similar to that found by 
Porto (1998) for the same species collected in the Meia Ponte River, Goiás, with the females predominating over the males. However, Silva et al. (2002) studying the same species collected in the State of Pará found the contrary, that is, males predominating over females.

The sexual proportion changed between the Macrobrachium species, so Barros (1995) and Ammar et al. (2001) studying the $M$. olfersii population of the coast of Santa Catarina and Mossolin and Bueno (2002) studying samples of the same species collected in the coastal waters of the State of São Paulo found a predominance of males over females at a proportion of 1: 0.53; 1: 0.71 and 1: 0.23 , respectively. Antunes and Oshiro (2004) found for M. potiuna, collected in the coast of the State of Rio de Janeiro, Brazil, a ratio of 1: 0.94 between males and females, higher than $M$. olfersii. On the other hand, Mantelatto and Barbosa (2005) discovered the opposite for M. brasiliense collected in Serra Azul, São Paulo, that is, females predominated over males in a proportion of 1:2.6.

\subsection{Reproductive cycle}

Pinheiro and Hebling (1998) assert that the reproductive period of freshwater decapods crustacean is closely associated to the rainy period, to thermal variations and to the photoperiod of the region where it happens.

The occurrence of ovigerous $M$. amazonicum females of the Jaguaribe River during the collection period indicates that this species is capable of reproducing the entire year, having a continuous reproduction. This observation is similar to the one by Chaves and Magalhães (1993); Bragagnoli and Grotta (1995); Bialetzki et al. (1997); Porto (1998) and Silva et al. (2002) for samples of the same species collected in various regions of Brazil.

The predominance of non-ovigerous females during most of the year of collection may be related to a difficulty in catching ovigerous females, since during the reproductive phase they migrate to estuary regions where egg incubation occurs or they look for shelter in protected areas, that is, in marginal plants to avoid predation pressure (Ismael and New, 2000).

Chaves and Magalhães (1993); Porto (1998) and Silva et al. (2002) observed that ovigerous M. amazonicum females are more abundant in the rainy season than at other times of the year. However, in the Jaguaribe River the occurrence of ovigerous females did not present any relation with the pluviometric configuration, perhaps due to the fact that the State of Ceará is located in a semi-arid region, which probably enabled the species to find a reproductive alternative.

That region of catching is characterized for having only two climatic seasons: the rainy one, whose pluviometric precipitations vary between 400 and $800 \mathrm{~mm}$ and dry. Rains that occur during the rainy season are concentrated in a short period that extend from February to May, the so-called "square winterly". During the dry season, that it extends from June to January; the pluviometric precipitations are placed below the average. These months are considered anomalous, therefore as they are situated in the extremities of the dry season, they can also include the rainy season.

\subsection{Ovarian maturation stages}

The four different phases of ovarian development for M. amazonicum females defined in this paper were very similar to the ones described by Porto (1998).

The occurrence of M. amazonicum females with mature ovaries within the group of non- ovigerous during the collection reinforces observations already made by Odinetz Collart (1991a); Bragagnoli and Grotta (1995); Bialetzki et al. (1997) and Porto (1998) that this species is characterized for presenting continuous reproductive activity.

Within the ovigerous group, a higher frequency of females with immature ovaries is expected as they are found in the middle of their gonadal development. However, ovigerous females with mature ovaries were found, although with a low frequency, which indicates that even carrying eggs, the $M$. amazonicum females immediately after spawning, can initiate a new reproductive cycle, again reinforcing that this species has continuous reproduction. According to Odinetz Collart (1991a), it is possible to find females with their ovaries in different stages of maturation, regardless of the season of the year.

\subsection{Size of first maturation}

In the State of Pará, Silva et al. (2002) found ovigerous $M$. amazonicum females with total lengths of $3.3 \mathrm{~cm}$, a smaller size than the ovigerous females collected in the Jaguaribe River, Ceará. This fact could be related to the type of trap used, because while in the North region the prawns were captured by means of a "puçá" of $17 \mathrm{~cm}$, in the region studied they were captured by means of a casting net of $20.0 \mathrm{~mm}$. This could possibly explain the difference of the average size of the females of first maturation captured in the Jaguaribe River, approximately $5.0 \mathrm{~cm}$, and the size of the smallest ovigerous females collected in Vigia, Pará by Silva et al. (2002).

Unfortunately, our results cannot be compared to those of Porto (1998), even though he has worked with M. amazonicum females, he used the relative frequency of carapace length to determine the age of the first maturation and not the total length, as suggested by Vazzoler (1982).

\section{Conclusions}

The physical-chemical parameters and pluviosity did not affect the population structure and reproduction of M. amazonicum. The occurrence of ovigerous and nonovigerous females with mature ovaries throughout the entire year reinforces the fact that this species possesses a type of continuous reproduction.

Acknowledgments - We are grateful to CNPq (Grants \# 479843/01-5) e FUNCAP (Grants \# 151/01) for fellowships that funded this research. We would also like to thank Dr. Irene Bastos Franceschini Vicentine and Dr. José Roberto Feitosa, 
who provided helpful comments and suggestions for this manuscript.

\section{References}

AMMAR, D., MÜLLER, YMR. and NAZARI, EM., 2001. Biologia reprodutiva de Macrobrachium olfersii (Wiegman) (Crustacea, Decapoda, Palaemonidae) coletados na Ilha de Santa Catarina, Brasil. Revta. bras. Zool., vol. 18, no. 2, p. 523-528.

ANTUNES, LS. and OSHIRO, LMY., 2004. Aspectos reprodutivos do camarão de água doce Macrobrachium potiuna (Crustacea, Decapoda, Palaemonidae) na Sena do Piloto, Mangaratiba, Rio de Janeiro, Brasil. Revta. Bras. Zool., 2004, vol. 21, no. 2, p. 261-266.

BARROS, MP., 1995. Dados biológicos sobre Macrobrachium olfersii (Wiegmann, 1836) (Decapoda, Palemonidae) da Praia da Vigia, Garopaba, Santa Catarina, Brasil. Biociências, vol. 3, no. 2 , p. $239-252$.

BIALETZKI, A., NAKATANI, K, BAUMGARTNER, G. and BOND-BUCKUP, G., 1997. Occurrence of Macrobrachium amazonicum (HeIler) (Decapoda, Palaemonidae) in Leopoldo's inlet (Ressaco do Leopoldo), upper Paraná River, Porto Rico, Paraná, Brasil. Revta. bras. Zool., vol. 14, no. 2, p. 379-390.

BISWAS, R. and QURESHI, TA., 1994. Annual reproductive cycle ofthe fresh water prawn. Macrobrachium dayanum (Henderson, 1893). Naturalia, vol. 19, p. 131-147.

BOND, G. and BUCKUP, L., 1982. O ciclo reprodutivo de Macrobrachium borelli (Nobili, 1896) e de Macrobrachium potiuna (Müller, 1 880) (Crustacea, Decapoda, Palaemonidae) e suas relações com a temperatura. Rev. Brasil. Biol., vol. 42, no. 3 , p. $473-483$.

BRAGAGNOLI, G., GROTTA, M., 1995. Reprodução do camarão de água doce Macrobrachium amazonicum do açude Epitácio Pessoa, Boqueirão (PB), Brasil. Parte 1: ciclo sexual. Rev. Nordestina de Biologia, vol. 10, no. 2, p. 141-154.

CARVALHO, HA. and PEREIRA, MCG., 1981. Descrição dos estádios ovarianos de Macrobrachium acanthurus (Wiegmann, 1836) (Crustacea, Palaemonidae) durante o ciclo reprodutivo. Ciência e Cultura, vol. 33, no. 10, p. 1353-1359.

CARVALHO-PINHEIRO, FIA., 1983. Reprodução do pitu Macrobrachium acanthurus (Wiegmann, 1836). Subsídio às atividades de cultivo. 1. Influência da temperatura Bolm. Fisiol. Animal Universidade de São Paulo, vol. 7, p. 95-101.

CHAVES. PTC. and MAGALHÃES, C., 1993. O desenvolvimento ovocitário em Macrobrachium amazonicum (HelIer, 1862) (Crustacea: Decapoda: Palaemonidae), camarão dulcícola da Região Amazônica. Acta Amazônica, vol. 23, no. 1, p. 17-23.

COELHO, PA. and RAMOS-PORTO, MA., 1985. Camarões de água doce do Brasil: distribuição geográfica. Revta. Brasil. Zool., vol. 2, no. 6, p. 405-4W.

FREITAS, JVF., MACHADO, ZL., GURGEL, JJS. and MEDEIROS, MAN., 1979. Pesquisas tecnológicas sobre o aproveitamento do camarão canela, Macrobrachium amazonicum (HelIer), dos açudes no Nordeste brasileiro. Bol. Técnico do DNOCS, vol. 37, no. 1, p. 63-84.

GAMBA, AL., 1984. Different egg-associated and larval development characteristics of Macrobrachium jelskii and Macrobrachium amazonicum (Arthropoda: Cmstacea) in a
Venezuelan continental lagoon. Intern. J. Invert. Reprod. Develop., vol. 7, p. 135-142.

GOMES-CORREA, MM., 1977. Palemonideos do Brasil (Crustacea-Decapoda-Natantia). MSc dissertation Universidade Federal do Rio de Janeiro - UFRJ, 191p.

GURGEL, JJS. and MATOS, MOM., 1984. Sobre a criação extensiva do camarão canela Macrobrachium amazonicum (HeIler) nos açudes públicos do nordeste brasileiro. In Resumos do Simpósio Brasileiro de Aqüicultura, Universidade de São Carlos, SP, p. 39.

HOLTHUJS, LB., 1952. A general revision of the Palemonidae (Crusiacea, Decapoda, Natantia) of the America. Allan Hancock Foundation Publications, Occasional Papers, vol. 12, 396p.

-, 1980. FAO species catalogue. Prawns and prawns of the world. An annotated catalogue of species of interest to fisheries. FAO Fish. Synopses, vol. 125, no. 1, 261p.

HOLTHUJS, LB., 2000. Nomenclature and Taxonomy. In NEW, MB., VALENTI, WC. (eds.) Fresh water prawn culture: the farming of Macrobrachium rosenbergii. London: Blackwell Science, p. 12-17.

IPLANCE. Atlas do Ceará, Fortaleza, 1995, 64p.

ISMAEL, D. and NEW, MB., 2000. Biology. In NEW, MB., VALENTI, WC. (Eds.) Freshwater prawn culture: the farming of Macrobrachium rosenbergii. London: Blackwell Science, p. $18-40$.

JALIHAL, DR., SANKOLL, KN. and SHENOY, S., 1993. Evolution of larval developmental patters and the process of freshwaterization in the prawn genus Macrobrachium Bate, 1868 (Decapoda, Palaemonidae). Crustaceana, vol. 65, no. 3, p. 365-376.

LOBÃO, VL. and ROJAS, NET. Camarões de água doce. Da coleta ao cultivo, à comercialização. São Paulo: Ícone, 1991. $112 \mathrm{p}$.

LOBÃO, VL., SAWAIA, P. and SANTOS, LE., 1978. Influência da temperatura, precipitação pluviométrica e insolação na reprodução de Macrobrachium holthuisi Genofre Lobão, 1976 (Crustacea - Decapoda). Bolm. Inst. Pesca, vol. 5, no. 2, p. 109-118.

LOBÃO, VL., ROJAS, NET. and VALENTI, WC., 1986. Fecundidade e fertilidade de Macrobrachium amazonicum (Heller, 1862) (Crustacea, Decapoda) em laboratório. Bolm. Inst. Pesca, vol. 13, no. 2, p. 15-20.

MANTELATTO, FLM. and BARBOSA, LR., 2005. Populations structure and relative growth of freshwater prawn Macrobrachium brasiliense (Decapoda, Palaemonidae) from São Paulo State, Brazil. Acta Limnol. Bras., vol. 17, no. 3, p. 245-255.

MARTIN, JW. and DAVIS, GE., 2001. An update classification of the recent Crustacea. Nat. Hist. Mus. Los Angeles, no. 39, p. 1-124.

MELO, GAS., 2003. Família Palaemonidae. In MELO, GAS. (ed.) Manual de identificação dos Crustacea Decapoda de água doce do Brasil. São Paulo: Loyola, p. 317-398.

MOSSOLIN, EC. and BUENO, SLS., 2002. Reproductive biology of Macrobrachium olfersi (Decapoda, Palaemonidae) in São Sebastião, Brazil. Journal of Crustacean Biology, vol. 22, no. 2, p. 367-376. 
NEW, MB., 2002. Farming freshwater prawns: a manual for the culture of the giant river prawn (Macrobrachium rosenbergii). FAO Fisheries Technical Paper, no. 428. 212p.

ODINETZ COLLART, O., 1991a. Tucurui dam and the populations of the prawn Macrobrachium amazonicum in the Lower Tocantins (Pa-Brasil): a four years study. Archiv. für Hidrobiologie, vol. 122, no. 2, p. 213-228.

-, 1991b. Stratégie de reproduction de Macrobrachium amazonicum en Amazonie Centrale. Crustaceana, vol. 61, no. 2, p. 253-270.

-, 1993. Ecologia e potencial pesqueiro do camarão canela Macrobrachium amazonicum, na bacia amazônica. In FERREIRA. EJG, SANTOS, GM., LEÃO, ELM. and OLIVEIRA, LA. (Eds.) Bases Científicas para Estratégias de Preservação e Desenvolvimento da Amazônia: Fatos e Perspectivas. Manaus: INPA, vol. 2, p. 254-289.

ODINETZ COLLART, O. and MAGALHÃES, C., 1994. Ecological constraints and life history strategies of Palaemonid prawns in Amazônia. Verhand International Limnologie, vol. 25 , p. $2460-2467$.

PAIVA, MP. and CAMPOS, E. Fauna do nordeste do Brasil: conhecimento científico e popular. Fortaleza: Banco do Nordeste do Brasil, 1995, 272p.

PINHEIRO, MAA. and HEBLING, NJ., 1998. Biologia de Macrobrachium amazonicum (De Man, 1879). In VALENTI, WC. (Ed.), Carcinicultura de água doce: Tecnologia para Produção de Camarões, São Paulo: FAPESP, Brasília: IBAMA, p. 21-46.

PINTO, EM. 1977. O camarão canela, Macrobrachium amazonicum (Heller), em açudes públicos do nordeste do Brasil administrados pelo Departamento Nacional de Obras contra as Secas (DNOCS). Bachelor's Monography, Universidade Federal do Ceará - UFC, 43p.

PORTO, LAC., 1998. Estrutura populacional e biologia reprodutiva de Macrobrachium amazonicum (Heller, 1862) (Crustacea, Decapoda, Palaemonidae) na bacia hidrográfica do Rio Meia Ponte, Bela Vista de Goiás-GO, Brasil. (PhD Thesis) - Universidade de São Paulo - USP, 117p.

REBOUÇAS, AF., 2002. Relações morfométricas de Macrobrachium amazonicum (Crustacea, Palemonidae) do Baixo Jaguaribe, Ceará. Bachelor's Monography, Universidade Estadual do Ceará - UECE, 35p.

RODRIGUEZ, G., 1980. Los crustaceos decapodos de Venezuela. Caracas: Instituto Venezolano de Investigaciones Cientificas, Caracas, 443 p.

SAGI, A. and RA'ANAN, Z., 1988. Morphotypic differentiation of males of the fresh-water prawn Macrobrachium rosenbergii: changes in the midgut glands and the reproductive system. $J$. Crustacean Biol., vol. 8, no. 1, p. 43-47.

SAMPAIO, CMS. and VALENTI, WC., 1996. Growth curves for Macrobrachium rosenbergii in semi-intensive culture in Brazil. J. Wor. Aquac. Soc., vol. 27, no. 3, p. 353-358.
SANTOS, JA., 2003. Diferenciação morfotípica em machos de Macrobrachium amazonicum (Crustacea, Palaemonidae). Bachelor's Monography, Universidade Estadual do CearáUECE, 35p.

SCAICO, MA., 1992. Fecundidade e fertilidade de Macrobrachium amazonicum (Crustacea, Decapoda) de um açude do nordeste brasileiro. Bolm. Inst. Pesca, vol. 19, p. 89-96.

SHORT, JW., 2004. A revision of Australian river prawn, Macrobrachium (Crustacea, Decapoda, Palaemonidae). Hydrobiologia, vol. 525, p. 1-110.

SILVA, KCA., SOUZA, RAL. and CINTRA, IHA., 2002. Camarão-cascudo Macrobrachium amazonicum (Heller, 1862) (Crustácea, Decapoda, Palemonidae) no município de Vigia, Pará, Brasil. Bol. Téc. Cient. Cepnor, vol. 2, no. 1, p. 41-73.

SILVA, RR., SAMPAIO, CMS., SANTOS, JA., 2002. Fecundity and fertility of Macrobrachium amazonicum (Crustacean, Palemonidae). Braz. J. Biol., vol. 64, no. 3A, p. 489-500.

SIPAÚBA-TAVARES, LH., 1998. Limnologia dos sistemas de cultivo. In VALENTI, WC. (Ed.). Carcinicultura de água doce: Tecnologia para Produção de Camarões, São Paulo: FAPESP, Brasília: IBAMA, p. 47-75.

VALENTI, WC., 1990. Criação de camarões de água doce Macrobrachium rosenbergii. In Anais da Reunião Anual da Sociedade Brasileira de Zootecnia, 27, Reunião da Associação Latino-Americana de Produção Animal, 12, Campinas. p. 757-785.

-, 1992. Current status of freshwater prawn farming in Brazil. SILAS, EG. (Ed.), Freshwater Prawns. India: Trissur, Kerala Agricultural University, p. 50-54.

-, 1993. Frehswater prawn culture in Brazil. World Aquaculture, vol. 21 , no. 1 , p. 29-34.

-, 1996. Criação de Camarões em Águas Interiores. Jaboticabal: Funep, Bol.Técnico do Caunesp, no. 2, 62p.

-, 2002. Situação atual, perspectivas e novas tecnologias para produção de camarões de água. In Anais do XII Simpósio Brasilerio de Aquicultura, junho 2002, Goiânia, p. 90-106.

VAZZOLER, AEA., 1982. Manual de métodos para estudos biológicos de populações de peixes. Reprodução e crescimento. 108p., CNPq, Programa Nacional de Zoologia, Brasília.

WILLIAMS, AB., 1984. Shrimps, lobsters and crabs of the Atlantic coast on the Estern United State, Maine to Florida. 550p., Smithsonian Institution Press, Washington.

ZIMMERMANN, S., 1998. Manejo da qualidade de água e do solo dos viveiros. In VALENTI, WC. (Ed.). Carcinicultura de água doce: Tecnologia para Produção de Camarões, São Paulo: FAPESP, Brasília: IBAMA, p. 217-238. 
